\title{
Beton Ringan dari Campuran Styrofoam dan Serbuk Gergaji dengan Semen Portland 250, 300 dan 350 kg/ $\mathrm{m}^{3}$
}

\author{
R. Buyung Anugraha $A^{1)}$, Sarithal Mustaza ${ }^{21}$ \\ 1) Staf Pengajar Program Studi Diploma Teknik Sipil FTSP ITS, 2) Staf Kementrian PU Aceh \\ r_buyung_aa@ce.its.ac.id
}

\begin{abstract}
ABSTRAK
Salah satu bahan bangunan yang mengalami perkembangan sangat pesat hingga saat ini adalah beton. Beberapa keunggulan beton antara lain harganya relatif murah, mempunyai kekuatan tekan tinggi, tahan terhadap karat, mudah diangkut dan dicetak, dan relatif tahan terhadap kebakaran. Namun, beton memiliki salah satu kelemahan yaitu berat jenis yang sangat tinggi sehingga beban mati pada suatu struktur menjadi sangat besar. Ada beberapa cara yang dapat dipakai untuk membuat beton menjadi ringan antara lain penggunaan agregat ringan, beton dibuat berongga dan beton dibuat tanpa pasir. Penjabaran dari permasalahan tersebut diatas, maka dibuat suatu penelitian beton ringan dari campuran styrofoam dan serbuk gergaji, dimana limbah kayu tersebut belum dimanfaatkan secara optimal. Pada penelitian ini dibuat suatu campuran beton ringan dari bahan styrofoam dan bahan serbuk gergaji dengan menggunakan kandungan semen portland sebanyak 250, 300 dan $350 \mathrm{~kg}$ tiap $\mathrm{m}^{3}$ beton. Adapun variasi perbandingan volume styrofoam dan serbuk gergaji adalah sebesar $0 \%$ 20\%, 40\%,60\%,80\% dan $100 \%$ dengan kondisi perlakuan terhadap benda uj i selama 28 hari direndam dan tidak direndam. Benda uj i dibuat silinder beton dengan ukuran diameter $150 \mathrm{~mm}$ dan tinggi $300 \mathrm{~mm}$. Penelitian ini untuk mengetahui berat $/ \mathrm{m}^{3}$, kuat tekan dan modulus elastisitas dari beton ringan yang dihasilkan. Hasil penelitian memperlihatkan bahwa peningkatan penggunaan serbuk gergaji menyebabkan berat beton menjadi lebih berat, kuat tekan dan nilai modulus elastisitas meningkat. Sebaliknya, peningkatan penggunaan styrofoam menyebabkan berat beton menjadi lebih ringan, kuat tekan dan nilai modulus elastisitas menurun. Berat tertinggi beton ringan ini pada umur 28 hari kondisi tidak direndam adalah $875 \mathrm{~kg} / \mathrm{m}^{3}(0 \%$ styrofoam $100 \%$ serbuk gergaji), sedangkan yang terendah adalah $322 \mathrm{~kg} / \mathrm{m}^{3}(100 \%$ styrofoam $0 \%$ serbuk gergaji). Benda uji kondisi tidak direndam mempunyai nilai kuat tekan dan nilai modulus elastisitas yang lebih baik dari pada benda uji dengan kondisi direndam.
\end{abstract}

Kata kunci : beton ringan, styrofoam dan serbuk gergaji.

\section{PENDAHULUAN}

\section{A. Latar Belakang}

Salah satu bahan bangunan yang mengalami perkembangan sangat pesat hingga saat ini adalah beton. Beberapa keunggulan beton antara lain harganya relatif murah, mempunyai kekuatan tekan tinggi, tahan terhadap karat, mudah diangkut dan dibentuk dan relatif tahan terhadap kebakaran. Beton memiliki salah satu kelemahan yaitu berat jenisnya yang cukup tinggi sehingga beban mati struktur menjadi sangat besar.

Beberapa cara yang dapat dipakai untuk mengurangi berat beton seperti dengan penggunaan agregat ringan, beton dibuat berongga dan beton dibuat tanpa pasir. Satyarno (2004)[1] telah melakukan penelitian penggunaan styrofoam untuk membuat beton ringan dengan menggunakan semen biasa atau tipe I. Hasil penelitian menunjukkan bahwa beton ini mempunyai berat yang jauh lebih kecil dibandingkan dengan beton normal. Alternatif lain yang dapat menjadi pertimbangan untuk penelitian yaitu penggunaan serbuk gergaj $i$ (saw dust) sebagai pengganti pasir. Limbah kayu tersebut selama ini belum dimanfaatkan secara optimal. Beton ringan campuran styrofoam, serbuk gergaji dan semen portland ini diharapkan dapat digunakan untuk bahan bangunan selain penggunaan batu bata dan batako.

Styrofoam atau expanded polystyrene dikenal sebagai gabus putih yang biasa digunakan untuk membungkus barang elektronik. Jika dibentuk granular maka 
berat satuannya menjadi sangat kecil yaitu hanya berkisar antara $13-16 \mathrm{~kg} / \mathrm{m}^{3}$. Penggunaan Styrofoam dalam beton dapat dianggap sebagai udara yang terjebak. Namun, keuntungan menggunakan styrofoam dibandingkan menggunakan rongga udara dalam beton berongga adalah styrofoam mempunyai kekuatan tarik (Satyarno, 2004)[1]. Serbuk gergaji (saw dust) merupakan limbah penggergajian yang dapat menimbulkan masalah dalam pembuangannya.

\section{B. Tujuan Penelitian}

Penelitian beton ringan dengan menggunakan styrofoam, serbuk gergaji dan semen portland bertujuan untuk :

1. Mengetahui sifat-sifat fisik dan mekanika beton ringan yang dihasilkan dengan menggunakan campuran antara styrofoam, serbuk gergaji dan semen portland yaitu besarnya kuat tekan beton dan modulus elastisitas dari beton ringan yang dihasilkan.

2. Mengetahui jumlah perbandingan yang tepat antara serbuk gergaji dan styrofoam untuk menghasilkan beton ringan dengan variasi jumlah semen portland sebesar $250 \mathrm{~kg} / \mathrm{m}^{3}, 300 \mathrm{~kg} / \mathrm{m}^{3}$ dan $350 \mathrm{~kg} / \mathrm{m}^{3}$.

3. Mengetahui efek perendaman terhadap berat beton dan kuat tekan beton ringan dari campuran styrofoam, serbuk gergaji dan semen portland.

\section{Manfaat Penelitian}

Manfaat penelitian ini adalah menambah alternatif penggunaan material baru dalam pembuatan suatu beton ringan yang berupa campuran styrofoam, serbuk gergaji dan semen portland. Diharapkan bahan alternatif ini dapat digunakan untuk bahan bangunan selain penggunaan batu bata dan batako.

\section{TINJ AUAN PUSTAKA}

\section{A. Beton ringan}

Beton ringan menurut SNI 03-3449-1994 merupakan beton dengan berat beton di bawah $1860 \mathrm{~kg} / \mathrm{m}^{3}$ dan kuat tekan maksimumnya $41.360 \mathrm{Mpa[2].} \mathrm{Jenis-jenis}$ beton ringan berdasarkan berat beton, kuat tekan dan agregatnya penyusunnya menurut SNI 03-3449-1994[3] seperti tabel 1 berikut.

Tabel $1 . \quad J$ enis-jenis beton ringan berdasarkan berat beton, kuat tekan dan agregat penyusunannya.

\begin{tabular}{|c|c|c|c|}
\hline \multirow[b]{2}{*}{$\begin{array}{l}\text { Konstruksi beton } \\
\text { ringan }\end{array}$} & \multicolumn{2}{|c|}{ Beton ringan } & \multirow[b]{2}{*}{ Jenis agregat ringan } \\
\hline & $\begin{array}{l}\text { Kuat } \\
\text { tekan } \\
\text { (MPa) }\end{array}$ & $\begin{array}{l}\text { Berat } \\
\text { beton } \\
\left(\mathrm{kg} / \mathrm{m}^{3}\right.\end{array}$ & \\
\hline $\begin{array}{l}\text { Struktural } \\
\text { - } \quad \text { Maksimum } \\
\text { - } \quad \text { Minimum }\end{array}$ & $\begin{array}{l}41,360 \\
17,240\end{array}$ & $\begin{array}{l}1860 \\
1400\end{array}$ & $\begin{array}{l}\text { Agregat ringan dibuat melalui } \\
\text { proses pemanasan dari batu } \\
\text { serpih, lempung, sabakterak besi } \\
\text { dan abu terbang }\end{array}$ \\
\hline $\begin{array}{l}\text { Struktural Ringan } \\
\text { : Maksimum } \\
\text { - Minimum }\end{array}$ & $\begin{array}{r}17,240 \\
6,890\end{array}$ & $\begin{array}{c}1400 \\
800\end{array}$ & $\begin{array}{l}\text { Agregat ringan lama: scoria atau } \\
\text { batu apung }\end{array}$ \\
\hline $\begin{array}{ll}\text { Struktural } & \text { Sangat } \\
\text { Ringan } & \\
\text { Sebagai Isolasi } \\
\text { - Maksimum } \\
\text { - Minimum }\end{array}$ & - & 800 & Perlit atau vermikulit \\
\hline
\end{tabular}

Dobrowolski (1998)[4], beton ringan merupakan beton dengan berat dibawah $1900 \mathrm{~kg} / \mathrm{m}^{3}$ sedangkan Neville dan Brooks (1987)[5] memberikan batasan beton ringan yaitu beton dengan berat di bawah 1800 $\mathrm{kg} / \mathrm{m}^{3}$.

Tabel 2. Jenis-jenis beton ringan berdasarkan berat beton dan kuat tekannya Dobrowolski (1998)[4] dan Neville dan Brooks (1987) [5]

\begin{tabular}{|c|l|c|c|}
\hline Sumber & \multicolumn{1}{|c|}{ Jenis beton ringan } & $\begin{array}{c}\text { Berat beton } \\
\left(\mathrm{kg} / \mathrm{m}^{3}\right)\end{array}$ & $\begin{array}{c}\text { Kuat tekan } \\
(\mathrm{MPa})\end{array}$ \\
\hline $\begin{array}{c}\text { Dobrowolski } \\
\text { (1998) }\end{array}$ & $\begin{array}{l}\text { Beton dengan berat jenis rendah } \\
\text { (Low-Density Concretes) }\end{array}$ & $240-800$ & $0,350-6,900$ \\
\cline { 2 - 4 } & $\begin{array}{l}\text { Beton ringan dengan kekuatan menengah } \\
\text { (Moderate-Strength Lightweight Concretes) }\end{array}$ & $800-1440$ & $6,900-17,300$ \\
\cline { 2 - 4 } & $\begin{array}{l}\text { Beton ringan struktur } \\
\text { (Structural Lightweight Concretes) }\end{array}$ & $1440-1900$ & $>17,300$ \\
\hline $\begin{array}{c}\text { Neville and } \\
\text { Brooks (1987) }\end{array}$ & $\begin{array}{l}\text { Beton ringan struktur } \\
\text { (Structural Lightweight Concretes) }\end{array}$ & $1400-1800$ & $>17,000$ \\
\cline { 2 - 4 } & $\begin{array}{l}\text { Beton ringan untuk pasangan bata } \\
\text { (Masonry Concrete) }\end{array}$ & $500-800$ & $7,000-14,000$ \\
\cline { 2 - 4 } & $\begin{array}{l}\text { Beton ringan penahan panas } \\
\text { (Insulating Concrete) }\end{array}$ & $<800$ & $0,700-7,000$ \\
\hline
\end{tabular}

Beton normal diperoleh dengan cara mencampurkan semen portland, air dan agregat, sedangkan untuk beton ringan bahan-bahan penyusunnya sangat tergantung pada jenis beton ringan tersebut. Menurut Raju (1983)[6] ada 3 jenis beton ringan yaitu beton agregat ringan, beton busa dan beton tanpa agregat halus. Hal senada juga disampaikan oleh Tjokrodimuljo (1996)[7], beberapa metode yang dapat digunakan untuk mengurangi berat beton antara lain adalah sebagai berikut :

1) Dengan membuat gelembunggelembung gas/udara dalam adukan semen.

2) Menggunakan agregat ringan, misalnya tanah liat bakar, batu apung atau agregat buatan.

3) Membuat beton tanpa menggunakan butir-butir agregat halus (beton non pasir).

Halaman 58 J urnal APLIKASI: Media Informasi \& Komunikasi Aplikasi Teknik Sipil Terkini 
Sambodo (2003)[8] melakukan penelitian membuat beton ringan dengan menggunakan styrofoam $\varnothing 4 \mathrm{~mm}$ campuran bahan beton styrofoam ringan yang digunakan untuk 1 $\mathrm{m}^{3}$ nya: semen $350 \mathrm{~kg}$ per $\mathrm{m}^{3}$, pasir $200 \mathrm{~kg}$ per $\mathrm{m}^{3}$, faktor air semen yang digunakan 0,45 dan styrofoam yang digunakan $1 \mathrm{~m}^{3}$ atau 1000 liter.

Hasil pengujian diperoleh berat jenis styrofoam 0,0142 ton per $\mathrm{m}^{3}$, berat jenis beton styrofoam ringan 0,718 ton per $\mathrm{m}^{3}$. kuat tekan silinder beton pada umur 28 hari $1.519 \mathrm{MPa}$.

Satyarno (2004)[1], telah melakukan penelitian penggunaan Styrofoam untuk pembuatan beton ringan yang menggunakan semen biasa atau Tipe 1. Hasil penelitian yang didapat menunjukkan bahwa beton dengan campuran styrofoam ini dapat mempunyai berat jenis yang jauh lebih kecil dibandingkan dengan beton normal. Jika beton normal mempunyai berat jenis sekitar $2400 \mathrm{~kg} / \mathrm{m}^{3}$. maka beton dengan campuran Styrofoam dapat mempunyai berat jenis hanya sekitar $600 \mathrm{~kg} / \mathrm{m}^{3}$. namun kuat tekan yang diperoleh juga lebih kecil yaitu sekitar 1.5 MPa sampai $2 \mathrm{MPa}$ yang mana cukup kecil jika dibandingkan dengan kuat tekan beton normal yang sekitar $20 \mathrm{MPa}$.

Wijaya (2005)[9], Sabbihiyah(2005) [10] dan Fatkhurohman (2005)[11], melakukan penelitian membuat beton ringan dengan menggunakan styrofoam $\varnothing$ 2-3 mm. Mix design yang dibuat memang berdasarkan percobaan di laboratorium dengan cara diuj $\mathrm{i}$ secara coba-coba dengan tuj uan agar nilai sebarnya memenuhi syarat, ternyata pada mix design akhir mengalami perubahan pada faktor air semennya. Hal ini karena jumlah air adukan yang didapat berdasarkan mix design awal tidak mencukupi untuk membuat adukan yang baik karena bertambahnya jumlah pasir dalam setiap variasi adukan, maka dalam pelaksanaannya terdapat koreksi berupa penambahan jumlah air pada kelipatan sebesar 2,5\% dari jumlah semen.

Dari penelitian tersebut juga didapat besarnya berat jenis, kuat tekan, modulus elastis sebagaimana terlihat pada tabel 3.

Untuk berat jenis semakin besar jumlah semen semakin besar berat jenis betonnya, begitu juga untuk kuat tekan semakin besar jumlah semen maka semakin besar kuat tekannya. Untuk modulus elastis beton kecenderungannya tidak selalu demikian pada setiap penambahan semen, kecuali pada kandungan semen $350 \mathrm{~kg}$ dengan persentase styrofoam $20 \%$ dan $0 \%$ Besarnya harga bahan per $\mathrm{m}^{3}$ terbesar pada persentase styrofoam $80 \%$ Untuk kandungan semen $250 \mathrm{~kg} / \mathrm{m}^{3}, 300 \mathrm{~kg} / \mathrm{m}^{3}$ dan $350 \mathrm{~kg} / \mathrm{m}^{3}$.

Tabel 3. Hasil penelitian Wijaya, Sabbihiyah dan Fatkhurohman (2005).

\begin{tabular}{|c|c|c|c|c|c|c|}
\hline \multirow{3}{*}{$\begin{array}{c}\text { Kondisi } \\
\text { Benda } \\
\text { Uji }\end{array}$} & \multicolumn{2}{|c|}{$\begin{array}{c}\text { Variasi } \\
\text { Perbandingan }\end{array}$} & \multirow{3}{*}{$\begin{array}{l}\text { Berat } \\
\text { Beton } \\
\text { Rerata } \\
\left(\mathrm{kg} / \mathrm{m}^{3}\right) \\
\end{array}$} & \multirow{3}{*}{$\begin{array}{l}\text { Kuat } \\
\text { Tekan } \\
\text { Rerata } \\
\text { (MPa) } \\
\end{array}$} & \multirow{3}{*}{$\begin{array}{c}\text { Modulus } \\
\text { Elastisitas } \\
\text { Rerata } \\
(\mathrm{MPa}) \\
\end{array}$} & \multirow{3}{*}{$\begin{array}{c}\text { Jumlah } \\
\text { Harga Bahan } \\
\text { Beton } / \mathrm{m}^{3} \\
\text { (Rp.) }\end{array}$} \\
\hline & & & & & \\
\hline & Styrofoam: & Pasir & & & & \\
\hline \multicolumn{7}{|c|}{ Semen $250 \mathrm{~kg} / \mathrm{m}^{3}$} \\
\hline \multirow{6}{*}{ 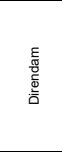 } & $100 \%$ : & $0 \%$ & 391 & 0.206 & \begin{tabular}{ll|l}
42.062 \\
\end{tabular} & 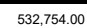 \\
\hline & $80 \%:$ & $20 \%$ & 817 & 0.944 & 182.571 & $565,272.25$ \\
\hline & $60 \%$ : & $40 \%$ & 1239 & 3.785 & 724.561 & $491,257.70$ \\
\hline & $40 \%:$ & $60 \%$ & 1568 & 4.169 & 533.546 & $379,844.00$ \\
\hline & $20 \%$ : & $80 \%$ & 1838 & 4.223 & 699.530 & $269,985.40$ \\
\hline & $0 \%$ & $100 \%$ & 2174 & 4.810 & 833.373 & $176,619.30$ \\
\hline \multirow{6}{*}{ 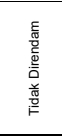 } & $100 \%:$ & $0 \%$ & 321 & 0.274 & 31.191 & $532,754.00$ \\
\hline & $80 \%$ : & $20 \%$ & 758 & 0.859 & 184.966 & $565,272.25$ \\
\hline & $60 \%$ : & $40 \%$ & 1157 & 2.689 & 445.083 & $491,257.70$ \\
\hline & $40 \%$ : & $60 \%$ & 1454 & 4.106 & 473.932 & $379,844.00$ \\
\hline & $20 \%$ : & $80 \%$ & 1726 & 4.998 & 686.083 & $269,985.40$ \\
\hline & $0 \%:$ & $100 \%$ & 1964 & 6.000 & 821.809 & $176,619.30$ \\
\hline \multicolumn{7}{|c|}{ Semen $300 \mathrm{~kg} / \mathrm{m}^{3}$} \\
\hline \multirow{6}{*}{ 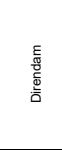 } & $100 \%$ : & $0 \%$ & 473 & 0.368 & 44.847 & $607,969.50$ \\
\hline & $80 \%$ : & $20 \%$ & 907 & 2.558 & 121.161 & $610,773.00$ \\
\hline & $60 \%$ : & $40 \%$ & 1274 & 4.869 & 296.300 & $514,519.50$ \\
\hline & $40 \%$ : & $60 \%$ & 1628 & 5.952 & 637.762 & $410,593.50$ \\
\hline & $20 \%$ : & $80 \%$ & 1845 & 9.785 & 998.230 & $290,655.00$ \\
\hline & $0 \%:$ & $100 \%$ & 2170 & 13.928 & 1214.425 & $201,319.50$ \\
\hline \multirow{6}{*}{ 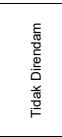 } & $100 \%:$ & $0 \%$ & 404 & 0.284 & 41.496 & $607,969.50$ \\
\hline & $80 \%$ : & $20 \%$ & 857 & 1.966 & 455.437 & $610,773.00$ \\
\hline & $60 \%:$ & $40 \%$ & 1223 & 4.577 & 682.762 & $514,519.50$ \\
\hline & $40 \%:$ & $60 \%$ & 1559 & 6.078 & 617.609 & $410,593.50$ \\
\hline & $20 \%$ : & $80 \%$ & 1772 & 10.499 & 1162.325 & $290,655.00$ \\
\hline & $0 \%$ & $100 \%$ & 1985 & 15.454 & 2248.861 & $201,319.50$ \\
\hline \multicolumn{7}{|c|}{ Semen $350 \mathrm{~kg} / \mathrm{m}^{3}$} \\
\hline \multirow{6}{*}{ 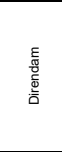 } & $100 \%:$ & $0 \%$ & 534 & 0.491 & 76.192 & $624,767.50$ \\
\hline & $80 \%$ : & $20 \%$ & 927 & 2.310 & 256.109 & $638,605.00$ \\
\hline & $60 \%$ : & $40 \%$ & 1274 & 3.997 & 689.121 & $528,655.00$ \\
\hline & $40 \%$ : & $60 \%$ & 1624 & 6.466 & 1031.783 & $425,282.50$ \\
\hline & $20 \%$ : & $80 \%$ & 1907 & 10.870 & 15750.911 & $325,107.50$ \\
\hline & $0 \%$ & $100 \%$ & 2214 & 17.902 & 22706.589 & $233,462.50$ \\
\hline \multirow{6}{*}{ 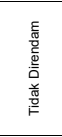 } & $100 \%:$ & $0 \%$ & 461 & 0.525 & 97.850 & $624,767.50$ \\
\hline & $80 \%$ : & $20 \%$ & 890 & 2.179 & 321.118 & $638,605.00$ \\
\hline & $60 \%$ : & $40 \%$ & 1190 & 3.448 & 610.629 & $528,655.00$ \\
\hline & $40 \%$ : & $60 \%$ & 1538 & 6.583 & 872.996 & $425,282.50$ \\
\hline & $20 \%$ : & $80 \%$ & 1797 & 10.507 & 14270.577 & $325,107.50$ \\
\hline & $0 \%:$ & $100 \%$ & 2057 & 17.385 & 17459.769 & $233,462.50$ \\
\hline
\end{tabular}

\section{B. Kuat tekan beton}

Beton sebagai bahan bangunan diperoleh dengan mencampurkan semen portland, air dan agregat dengan perbandingan tertentu. Pencampuran dilakukan sampai warna adukan tampak rata, kelecakan yang cukup (tidak cair dan tidak padat) dan tampak campurannya juga homogen. Campuran tersebut jika dituang ke dalam cetakan kemudian dibiarkan maka akan mengeras seperti batuan. Pengerasan itu terjadi 
karena adanya peristiwa reaksi antara air dan semen, yang berlangsung dalam waktu yang panjang dan akibatnya campuran itu selalu bertambah keras setara dengan umurnya. Di dalam adukan beton air dan semen membentuk pasta yang disebut pasta semen. Pasta tersebut selain mengisi poripori di antara butiran-butiran agregat halus juga sebagai perekat atau pengikat selama dalam proses pengerasan, sehingga butiranbutiran agregat saling terikat dengan kuat dan terbentuklah suatu massa yang kompak dan padat.

Dalam pembuatan campuran beton ada beberapa hal yang mempengaruhi kekuatan beton antara lain :

a. Faktor air semen (fas). Faktor air semen adalah perbandingan antara berat air dengan berat semen. Semakin rendah nilai fas semakin tinggi kuat tekannya. Namun pada kenyataannya pada suatu nilai faktor air-semen tertentu, semakin rendah nilai fas, kuat tekan beton semakin rendah, karena dengan fas terlalu rendah adukan beton sulit dipadatkan. Dengan demikian ada nilai fas tertentu yang optimum yang menghasilkan kuat tekan beton maksimum, lihat Gambar 1.

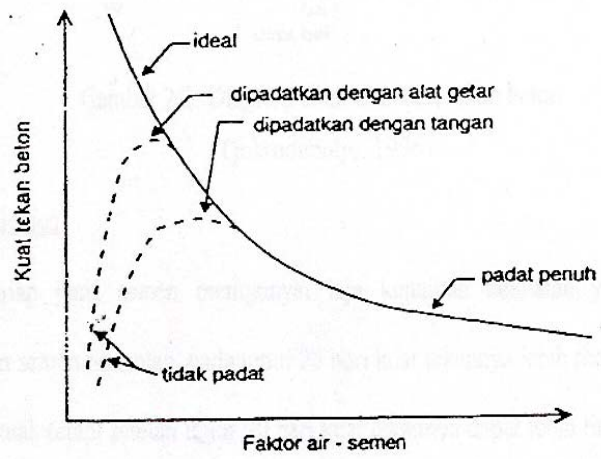

Gambar 1. Hubungan faktor air semen dengan kuat tekan beton (Tjokrodimuljo, 1996)[7]

b. Umur beton. Kuat tekan beton bertambah sesuai dengan bertambahnya umur beton. Kecepatan bertambahnya kekuatan beton tersebut sangat dipengaruhi oleh berbagai faktor antara lain fas dan suhu perawatan. Semakin tinggi fas semakin lambat kenaikan kekuatan betonnya dan semakin tinggi suhu perawatan semakin cepat kenaikan kekuatan betonnya, lihat Gambar 2.

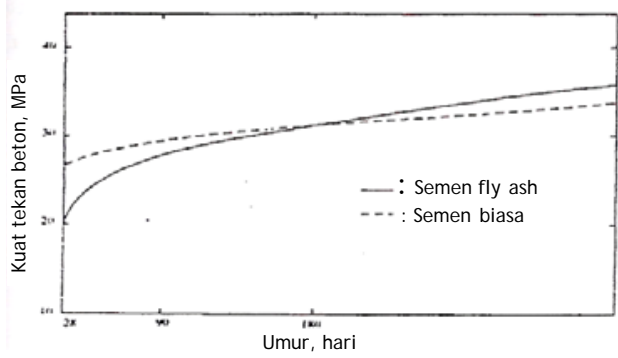

Gambar 2. Umur dan kuat tekan beton (Tjokrodimuljo, 1996)[7]

c. Jenis semen. Setiap jenis semen mempunyai laju kenaikan kekuatan yang berbeda. Pemakaian semen pozzolan, pada umur 28 hari kuat tekannya lebih rendah dari pada beton normal, tetapi setelah umur 90 hari kuat tekannya dapat lebih tinggi, sehingga penggunaan atau pemilihan jenis semen tergantung pada fungsinya.

Semen portland dibagi menjadi 5 jenis, yaitu :

Jenis I Semen portland untuk penggunaan umum yang tidak memerlukan persyaratan khusus.

J enis II Semen portland yang dalam penggunaannya memerlukan ketahanan terhadap sulfat dan panas hidrasi sedang.

Jenis III Semen portland yang dalam penggunaannya menuntut persyaratan kekuatan awal yang tinggi setelah pengikatan terjadi.

J enis IV Semen portland yang dalam penggunaannya menuntut persyaratan panas hidrasi yang rendah.

J enis V Semen portland yang dalam penggunaannya menuntut persyaratan sangat tahan terhadap sulfat.

d. J umlah semen. J umlah kandungan semen berpengaruh terhadap kuat tekan beton. Dalam kondisi fas yang sama beton dengan jumlah kandungan semen tertentu mempunyai nilai kuat tekan tertinggi. Bila jumlah semen yang 
digunakan terlalu sedikit dan jumlah air yang digunakan juga sedikit maka adukan beton akan sulit dipadatkan karena kekurangan air, sehingga kuat tekannya rendah, jika jumlah semen yang digunakan berlebihan dan penggunaan air juga berlebihan maka beton akan terlalu encer sehingga akan menjadi berpori, akibatnya kuat tekan beton rendah, lihat Gambar 3.

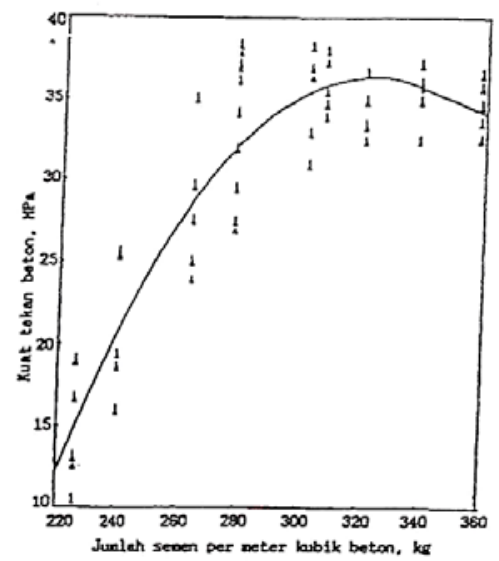

Gambar 3. Pengaruh jumlah semen terhadap kuat tekan beton pada faktor air semen sama (Tjokrodimuljo, 1996)[7]

e. Sifat agregat. Menurut Tjokrodimulyo (2004)[12], sifat agregat yang paling berpengaruh terhadap kekuatan beton adalah berat jenis, berat satuan, serapan air, gradasi butiran, keausan dan kekerasan.

f. Styrofoam. Styrofoam termasuk dalam kategori polimer sintetik dengan berat molekul tinggi. Polimer sintetik berbahan baku monomer berbasis etilina serta berbagai turunannya yang berasal dari perengkahan minyak bumi. Styrofoam hanya sebuah nama dalam dunia perdagangan, nama yang sesungguhnya adalah polystyrene atau poli (feniletena) dalam bentuk foam. Feniletena atau styrene dapat dipolimerkan dengan menggunakan panas, sinar ultra violet atau katalis. Poli(feniletena) merupakan bahan termo plastik yang bening (kecuali jika ditambahkan pewarna atau pengisi), dan dapat dilunakkan pada suhu sekitar $100^{\circ} \mathrm{C}$. Poli (feniletena) tahan terhadap asam, basa dan zat pengarat (korosi) lainnya, tetapi mudah larut dalam hidrokarbon aromatik dan berklor. Dalam propanon (aseton) poli (feniletena) hanya menggembung. Penyinaran dalam waktu lama oleh sinar ultra-ungu, sinar putih atau panas, sedikit mempengaruhi kekuatan dan ketahanan polimer terhadap panas. Poli (feniletena) berbusa atau styrofoam diperoleh dari pemanasan poli (feniletena) yang menyerap hidrokarbon volatil. Ketika dipanasi oleh kukus (steam), butiran akan melunak, dan penguapan oleh hidrokarbon di dalam butiran akan menyebabkan butiran mengembang, (Crawford, R. . ., 1998)[13]

g. Serbuk gergaji. Serbuk gergaj i berfungsi sebagai agregat halus yang akan mengisi pori-pori diantara butiran styrofoam. Serbuk gergaji yang digunakan terlebih dahulu diuji untuk mengetahui kebutuhan dalam per meter kubik beton. Pada saat pengujian berat satuan kondisi serbuk gergaji adalah jenuh kering muka (Saturated Surface Dry).

Sebelum dilakukan pengadukan atau pencampuran bahan ada beberapa perlakuan yang dilakukan terhadap serbuk gergaji yaitu direndam selama 2 (dua) sampai dengan 3 (tiga) hari yang bertujuan untuk menghilangkan kadar gula dan mengeluarkan getah yang diharapkan akan diperoleh serbuk gergaji yang lebih awet dan mudah mengikat dengan semen Ismeddiyanto (1998)[14]. Selanjutnya serbuk diangin-anginkan sampai dengan kondisi jenuh kering muka (SSD).

h. Modulus elastis beton. Modulus elastis adalah kemiringan kurva tegangan regangan beton pada kondisi linier. Menurut Wang dan Salmon (1986)[15] dari suatu kurva tegangan-regangan beton, dapat diperoleh modulus awal, modulus tangen (tangen modulus) dan modulus sekan (secant modulus) Modulus sekan yang ditentukan pada saat kuat tekan beton mencapai 25\% - 50\% dari kuat tekan beton maksimum biasanya disebut sebagai modulus elastisitas untuk bahan beton.

Ada beberapa faktor yang dapat mempengaruhi modulus elastisitas beton 
yaitu kelembaban beton, agregat dan modulus halus agregat (Neville and Brooks, 1987)[5].

Beberapa rumus empirik yang dapat digunakan untuk menentukan modulus elasititas beton antara lain :

a. SNI 03-2847-2002 memberikan persamaan untuk menghitung modulus elastisitas :

$$
\begin{aligned}
& \mathrm{E}_{\mathrm{c}}=0,043 \mathrm{w}_{\mathrm{c}}^{1,5} \sqrt{\mathrm{f}^{\prime} \mathrm{c}} \\
& \operatorname{dimana} \\
& W c=\text { Berat jenis beton }\left(\mathrm{kg} / \mathrm{m}^{3}\right) \\
& f^{\prime} \mathrm{c}=\text { Kuat tekan beton }(\mathrm{MPa}) \\
& E c=\text { Modulus elastisitas beton } \\
& (\mathrm{MPa})
\end{aligned}
$$

Persamaan 1 hanya berlaku untuk beton dengan berat $1500 \mathrm{~kg} / \mathrm{m}^{3}$ $2500 \mathrm{~kg} / \mathrm{m}^{3}$, sedangkan bila berat beton $\pm 2300 \mathrm{~kg} / \mathrm{m}^{3}$ maka digunakan persamaan berikut :

$$
E_{c}=4700 \sqrt{f^{\prime} c}
$$

b. Wang dan Salmon (1986)[15], dengan menentukan modulus sekan (secant modulus) dari kurva teganganregangan beton menggunakan rumus :

$$
E c i=\frac{f^{\prime} \mathrm{ci}}{\varepsilon i}=\mathrm{Ec}^{2}
$$

dimana :

$E C i=$ modulus sekan beton tekan (MPa)

$$
f^{\prime} c i=\text { kuat tekan beton }
$$$$
=f 2=0,5 \mathrm{f}^{\prime} \mathrm{c} \mathrm{MPa}
$$

$\varepsilon i=\varepsilon$ regangan pada beton saat

$$
\text { tegangan beton mencapai f'ci }
$$

Wang dan Salmon (1986)[15] mengemukakan bahwa ada 3 metode yang biasa digunakan untuk mendapatkan modulus elastisitas dari diagram tegangan-regangan yaitu :

a. Modulus awal

Nilai ini didapat dengan menarik garis singgung pada titik asal kurva tegangan-regangan. Nilai modulus awal adalah kemiringan garis singgung kurva tegangan-regangan pada titik asal.

b. Modulus tangen

Modulus tangen didapat dengan membuat garis singgung kurva tegangan-regangan pada suatu titik kurva. Kemiringan garis singgung ini dinamakan modulus tangen.

c. Modulus sekan

Modulus sekan didapat dengan menarik garis lurus dari titik asal ke suatu titik pada kurva. Kemiringan garis itulah yang dinamakan modulus sekan.

Penjelasan tentang modulus awal, modulus tangent dan modulus sekan dalam bentuk grafik dapat dilihat pada gambar 4 .

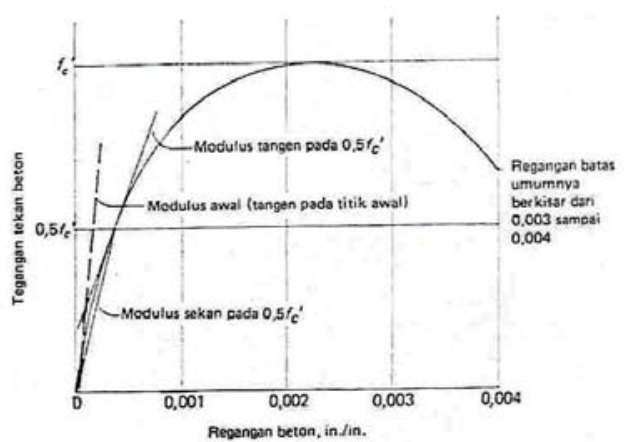

Gambar 4. Kurva tegangan-regangan untuk beton dalam tekan (Wang dan Salmon, 1986)[15]

\section{METODOLOGI PENELITIAN}

\section{A. Bahan dan Benda Uji}

Pada penelitian beton ringan campuran styrofoam, serbuk gergaji dan semen Portland ini digunakan bahan-bahan sebagai berikut :

1. Air yang digunakan sesuai persyaratan SNI 03-2847-2002.

2. Semen portland adalah semen portland jenis I produksi PT. SEMEN GRESIK.

3. Styrofoam berdiameter maksimum 7 mm produksi PT. GABUS PUTIH J akarta.

4. Serbuk gergaji merupakan serbuk gergaji kayu jati.

5. Benda uj $\mathrm{i}$ berupa silinder beton diameter $150 \mathrm{~mm}$ dan tinggi $300 \mathrm{~mm}$. J umlah sampel sebanyak 6 (enam) buah dari tiap variasi campuran, terdiri dari 3 (tiga) buah untuk direndam dan 3 (tiga) buah tidak direndam. 
Tabel 4. Variasi dan jumlah benda uj $\mathrm{i}$

\begin{tabular}{|c|c|c|c|c|c|c|c|c|}
\hline \multirow[b]{2}{*}{ No. } & \multirow[b]{2}{*}{$\begin{array}{l}\text { Variasi } \\
\text { Adukan }\end{array}$} & \multirow[b]{2}{*}{ Kode Beton } & \multirow[b]{2}{*}{$\begin{array}{l}\text { Semen } \\
\left(\mathrm{kg} / \mathrm{m}^{3}\right)\end{array}$} & \multirow[b]{2}{*}{$\begin{array}{c}\text { Air } \\
\text { (liter) }\end{array}$} & \multicolumn{2}{|c|}{$\begin{array}{l}\text { Perbandingan } \\
\text { Volume Bahan }\end{array}$} & \multicolumn{2}{|c|}{$\begin{array}{l}\text { J Ih Benda Uji } \\
\text { Sil linder Beton }\end{array}$} \\
\hline & & & & & Styrofoam & $\begin{array}{l}\text { Serbuk } \\
\text { Gergaji }\end{array}$ & \begin{tabular}{|c}
$\begin{array}{c}\text { Direndam } \\
\text { (Buah) }\end{array}$ \\
\end{tabular} & \begin{tabular}{|c|} 
Tidak \\
Direndam \\
(Buah)
\end{tabular} \\
\hline 1 & I & S250-ST100-SG0 & 250 & & $100 \%$ & $0 \%$ & 3 & 3 \\
\hline 2 & ॥ & S250-ST80-SG20 & 250 & Sesuai & $80 \%$ & $20 \%$ & 3 & 3 \\
\hline 3 & III & S250-ST60-SG40 & 250 & Uji & $60 \%$ & $40 \%$ & 3 & 3 \\
\hline 4 & IV & S250-ST40-SG60 & 250 & Sebar & $40 \%$ & $60 \%$ & 3 & 3 \\
\hline 5 & v & S250-ST20-SG80 & 250 & & $20 \%$ & $80 \%$ & 3 & 3 \\
\hline 6 & vi & S250-STO-SG100 & 250 & & $0 \%$ & $100 \%$ & 3 & 3 \\
\hline 7 & I & S300-ST100-SG0 & 300 & & $100 \%$ & $0 \%$ & 3 & 3 \\
\hline 8 & $\|$ & S300-ST80-SG20 & 300 & Sesuai & $80 \%$ & $20 \%$ & 3 & 3 \\
\hline 9 & III & S300-ST60-SG40 & 300 & Uji & $60 \%$ & $40 \%$ & 3 & 3 \\
\hline 10 & IV & S300-ST40-SG60 & 300 & Sebar & $40 \%$ & $60 \%$ & 3 & 3 \\
\hline 11 & v & S300-ST20-SG80 & 300 & & $20 \%$ & $80 \%$ & 3 & 3 \\
\hline 12 & vi & S300-STO-SG100 & 300 & & $0 \%$ & $100 \%$ & 3 & 3 \\
\hline 13 & I & S350-ST100-SG0 & 350 & & $100 \%$ & $0 \%$ & 3 & 3 \\
\hline 14 & ॥ & S350-ST80-SG20 & 350 & Sesuai & $80 \%$ & $20 \%$ & 3 & 3 \\
\hline 15 & III & S350-ST60-SG40 & 350 & Uji & $60 \%$ & $40 \%$ & 3 & 3 \\
\hline 16 & IV & S350-ST40-SG60 & 350 & Sebar & $40 \%$ & $60 \%$ & 3 & 3 \\
\hline 17 & v & S350-ST20-SG80 & 350 & & $20 \%$ & $80 \%$ & 3 & 3 \\
\hline 18 & vi & S350-ST0-SG100 & 350 & & $0 \%$ & $100 \%$ & 3 & 3 \\
\hline \multicolumn{7}{|c|}{ Jumlah benda uji (buah) } & 54 & 54 \\
\hline Jum & ah total b & enda uji (buah) & & & & & \multicolumn{2}{|c|}{108} \\
\hline
\end{tabular}

\section{B. Peralatan}

Peralatan yang digunakan dalam pengujian ini adalah timbangan, cetakan silinder beton, mesin pengaduk beton (mixer), literan, gelas ukur, meja sebar, bak perendaman, alat capping, mesin uji tekan beton, sendok semen/ sendok spesi, cetok, ember, kaliper/jangka sorong dan alat pendukung yang lainnya.

\section{Tahapan Penelitian}

Tahapan yang dilakukan pada pelaksanaan pelitian ini dibagi menjadi beberapa tahapan sebagai berikut :

1. Tahap persiapan

a. Penyiapan bahan dan pemeriksaan bahan

b. Pemeriksaan berat satuan styrofoam dan serbuk gergaj $i$

2. Tahap perencanaan campuran adukan beton

a. Menghitung kebutuhan bahan dengan menggunakan tabel mix design awal

b. Menghitung volume total bahan yang dibutuhkan untuk pembuatan benda uji.

3. Tahap pelaksanaan

Persiapan cetakan beton, pencampuran bahan adukan beton, pemeriksaan nilai sebar adukan beton, pembuatan silinder beton, perawatan, penimbangan dan perendaman benda uji dan pengujian kuat tekan.

\section{Analisis Hasil}

1. Berat beton dihitung dengan rumus:

$$
B_{j}=\frac{W}{\frac{\pi}{4} d^{2} H}
$$

dimana,

$$
W \text { = berat silinder beton, } \mathrm{kg}
$$

$d$ = diameter silider beton, $m$.

$H=$ tinggi silinder beton, $m$.

2. Kuat tekan silinder beton dengan rumus:

$$
f_{c}{ }^{\prime}=\frac{P}{\frac{\pi}{4} d^{2}}
$$

dimana,

$f_{c^{\prime}}{ }^{\prime}=$ kuat tekan silinder beton, $M P a$.

$P$ = beban maksimum, $N$

$d$ = diameter silinder beton, $\mathrm{mm}$

3. Modulus elastisitas silinder beton dihitung dengan menggunakan modulus sekan (secant modulus) dari kurva tegangan-regangan beton dengan rumus:

$$
E_{c i}=\frac{f_{c i}^{\prime}}{\dot{d}}=E_{c 2}
$$

dimana,

$$
\begin{aligned}
E_{c i}= & \text { Modulus sekan beton tekan, } \mathrm{MPa} \\
f^{\prime}{ }_{c i}= & \text { Kuat tekan beton } \\
= & f_{2}=0,500 f^{\prime}{ }_{c}, \mathrm{MPa} . \\
\varepsilon i= & \text { Regangan pada beton saat } \\
& \text { tegangan beton mencapai } f^{\prime}{ }_{c i} .
\end{aligned}
$$

\section{HASIL DAN PEMBAHASAN}

\section{A. Bahan Penyusun Beton Ringan}

Bahan-bahan yang digunakan dalam pembutan benda uji pada penelitian ini adalah:

1. Semen portland tipe I, berdasarkan hasil pengamatan secara visual menunjukkan bahwa, semen yang dipakai masih dalam kondisi baik.

2. Styrofoam, berdasarkan hasil pemeriksaan memiliki berat satuan $15.243 \mathrm{~kg} / \mathrm{m}^{3}$ dengan diameter beragam antara 2-7 mm.

3. Serbuk gergaji (kayu jati) memiliki berat satuan $283,794 \mathrm{~kg} / \mathrm{m}^{3}$ dengan modulus halus butir (mhb) yaitu 1,94, kondisi serbuk gergaji adalah SSD (jenuh kering muka).

4. Air memenuhi persyaratan. 


\section{B. Perhitungan Kebutuhan Bahan}

Kebutuhan bahan sehubungan dengan pembuatan benda uji sebagaimana pada tabel 4 diatas dapat dilihat pada tabel berikut.

Tabel 5. J umlah kebutuhan bahan

\begin{tabular}{|c|c|c|c|c|c|c|c|}
\hline No. & Kode & Fas & $\begin{array}{c}\text { Semen } \\
(\mathrm{kg})\end{array}$ & $\begin{array}{c}\text { Air } \\
(\mathrm{kg})\end{array}$ & $\begin{array}{c}\text { Styrofoam } \\
(\mathrm{kg})\end{array}$ & $\begin{array}{c}\text { Serbuk } \\
(\mathrm{kg})\end{array}$ & $\begin{array}{c}\text { Jumlah } \\
(\mathrm{kg})\end{array}$ \\
\hline 1 & 2 & 3 & 4 & 5 & 6 & 7 & 8 \\
\hline 1 & S250-ST100-SG0 & 0.400 & 250.480 & 100.192 & 19.090 & 0.000 & 369.762 \\
2 & S250-ST80-SG20 & 0.575 & 221.751 & 127.507 & 14.602 & 67.966 & 431.826 \\
3 & S250-ST60-SG40 & 0.775 & 271.421 & 210.352 & 14.398 & 178.704 & 674.874 \\
4 & S250-ST40-SG60 & 1.075 & 269.298 & 289.495 & 9.523 & 265.959 & 834.275 \\
5 & S250-ST20-SG80 & 1.100 & 296.771 & 326.449 & 4.886 & 363.840 & 991.946 \\
6 & S250-ST0-SG100 & 1.450 & 277.959 & 403.040 & 0.000 & 520.628 & 1201.627 \\
\hline 7 & S300-ST100-SG0 & 0.400 & 344.309 & 137.724 & 21.869 & 0.000 & 503.901 \\
8 & S300-ST80-SG20 & 0.525 & 314.150 & 164.929 & 17.238 & 80.238 & 576.555 \\
9 & S300-ST60-SG40 & 0.725 & 311.279 & 225.678 & 13.997 & 173.733 & 724.687 \\
10 & S300-ST40-SG60 & 0.950 & 304.430 & 289.208 & 8.971 & 250.547 & 853.156 \\
11 & S300-ST20-SG80 & 1.000 & 312.095 & 312.095 & 4.710 & 350.740 & 979.640 \\
12 & S300-ST0-SG100 & 1.050 & 347.040 & 364.392 & 0.000 & 492.439 & 1203.872 \\
\hline 13 & S300-ST100-SG0 0 & 0.400 & 313.310 & 125.324 & 17.057 & 0.000 & 455.691 \\
14 & S350-ST80-SG20 & 0.475 & 378.177 & 179.635 & 17.787 & 82.793 & 658.391 \\
15 & S350-ST60-SG40 & 0.675 & 351.680 & 237.384 & 13.555 & 168.241 & 770.860 \\
16 & S350-ST40-SG60 & 0.875 & 347.013 & 303.636 & 8.464 & 236.353 & 895.466 \\
17 & S350-ST20-SG80 & 0.850 & 354.150 & 301.028 & 4.580 & 341.145 & 1000.903 \\
18 & S350-ST0-SG100 & 0.875 & 398.106 & 348.343 & 0.000 & 468.060 & 1214.510 \\
\hline
\end{tabular}

\section{Berat Beton}

1. Berat beton rerata umur 1 dan 28 hari Berat beton yang diperiksa pada penelitian ini dibedakan menjadi berat beton kondisi direndam dan berat beton tidak direndam. Berat satuan beton merupakan perbandingan berat beton dengan volume beton tersebut.

Berdasarkan hasil perhitungan berat beton dapat dilihat adanya perbedaan berat beton terhadap berbagai variasi campuran yang dibuat. Semakin banyak serbuk gergaji yang digunakan maka semakin besar berat betonnya.

Tabel 6. Hasil pemeriksaan berat satuan beton

\begin{tabular}{|c|c|c|c|c|c|c|c|}
\hline \multirow{3}{*}{ No. } & \multirow{3}{*}{$\begin{array}{l}\text { Variasi } \\
\text { Adukan }\end{array}$} & \multirow{3}{*}{ Kode Beton } & \multicolumn{2}{|c|}{$\begin{array}{l}\text { Perbandingan } \\
\text { Volume Bahan }\end{array}$} & \multicolumn{3}{|c|}{$\begin{array}{c}\text { Berat Beton Rerata } \\
\left(\mathrm{kg} / \mathrm{m}^{3}\right)\end{array}$} \\
\hline & & & \multirow{2}{*}{ Styrofoam } & \multirow{2}{*}{$\begin{array}{l}\text { Serbuk } \\
\text { Gergaji }\end{array}$} & \multirow{2}{*}{$\begin{array}{l}\text { Umur } \\
1 \text { hari }\end{array}$} & \multicolumn{2}{|c|}{ Umur 28 hari } \\
\hline & & & & & & Direndam & $\begin{array}{c}\text { Tidak } \\
\text { Direndam }\end{array}$ \\
\hline 1 & I & S250-ST100-SG0 & $100 \%$ & $0 \%$ & 353.329 & 330.385 & 322.751 \\
\hline 2 & II & S250-ST80-SG20 & $80 \%$ & $20 \%$ & 413.450 & 470.637 & 405.389 \\
\hline 3 & III & S250-ST60-SG40 & $60 \%$ & $40 \%$ & 635.751 & 614.119 & 462.394 \\
\hline 4 & IV & S250-ST40-SG60 & $40 \%$ & $60 \%$ & 794.069 & 797.921 & 578.277 \\
\hline 5 & V & S250-ST20-SG80 & $20 \%$ & $80 \%$ & 901.419 & 921.674 & 711.968 \\
\hline 6 & VI & S250-STO-SG100 & $0 \%$ & $100 \%$ & 1084.444 & 1061.855 & 778.107 \\
\hline 7 & I & S300-ST100-SG0 & $100 \%$ & $0 \%$ & 464.380 & 430.211 & 367.374 \\
\hline 8 & II & S300-ST80-SG20 & $80 \%$ & $20 \%$ & 519.845 & 557.160 & 506.746 \\
\hline 9 & III & S300-ST60-SG40 & $60 \%$ & $40 \%$ & 687.041 & 690.792 & 544.251 \\
\hline 10 & IV & S300-ST40-SG60 & $40 \%$ & $60 \%$ & 766.882 & 822.863 & 606.782 \\
\hline 11 & $\mathrm{~V}$ & S300-ST20-SG80 & $20 \%$ & $80 \%$ & 905.924 & 912.785 & 725.290 \\
\hline 12 & VI & S300-STO-SG100 & $0 \%$ & $100 \%$ & 1134.226 & 1077.824 & 872.760 \\
\hline 13 & I & S350-ST100-SG0 & $100 \%$ & $0 \%$ & 421.299 & 441.679 & 396.597 \\
\hline 14 & II & S350-ST80-SG20 & $80 \%$ & $20 \%$ & 602.752 & 619.014 & 557.818 \\
\hline 15 & III & S350-ST60-SG40 & $60 \%$ & $40 \%$ & 733.710 & 714.290 & 606.638 \\
\hline 16 & IV & S350-ST40-SG60 & $40 \%$ & $60 \%$ & 797.063 & 838.749 & 632.044 \\
\hline 17 & $\mathrm{~V}$ & S350-ST20-SG80 & $20 \%$ & $80 \%$ & 957.299 & 958.046 & 751.780 \\
\hline 18 & VI & S350-STO-SG100 & $0 \%$ & $100 \%$ & 1110.109 & 1069.646 & 874.763 \\
\hline
\end{tabular}

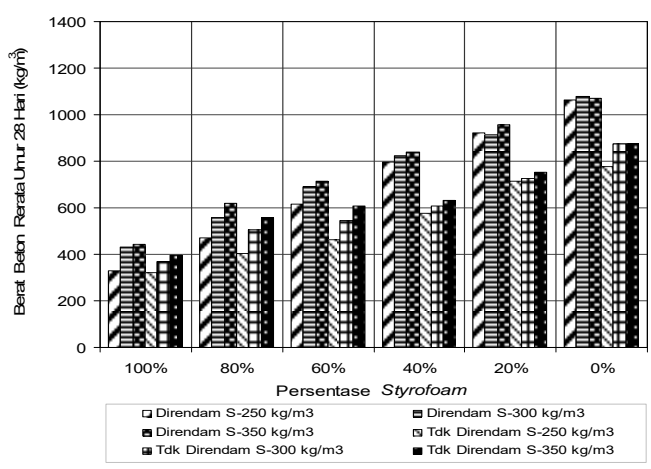

Gambar 5. Grafik hubungan variasi campuran dengan berat beton rerata pada umur 28 hari

2. Penggolongan beton ringan berdasarkan berat beton.

Jika berpedoman pada SNI 03-28472002[2], maka sebagian besar berat beton ringan pada penelitian ini termasuk golongan struktur ringan sebagai isolator, penggolongan Dobrowolski (1998)[4] termasuk beton dengan berat jenis rendah, penggolongan Neville and Brooks (1987)[5] termasuk beton ringan penahan panas dan menurut Satyarno (2004)[1] termasuk golongan beton non struktur.

\section{Kuat Tekan Beton}

1. Hasil pengujian kuat tekan beton

Pengujian kuat tekan beton dilakukan pada saat beton mencapai umur 28 hari. Pengujian dilakukan terhadap seluruh benda uji yang berjumlah 108 buah benda uji yang terdiri dari 18 variasi direndam (D) dan 18 variasi yang tidak direndam (TD). Setiap variasi terdiri dari 3 buah benda uji. Pada penelitian ini pengujian dilakukan beberapa tahap sesuai dengan waktu pembuatan benda uji. Sebelum pengujian seluruh benda uj $\mathrm{i}$ terlebih dahulu dicapping untuk mendapatkan permukaan tekan yang rata. 

ISSN.1907-753X

Tabel 7. Hasil pengujian kuat tekan rerata

\begin{tabular}{|c|c|c|c|c|c|c|c|}
\hline \multirow[t]{2}{*}{ No. } & \multirow{2}{*}{$\begin{array}{l}\text { Variasi } \\
\text { Adukan }\end{array}$} & \multirow{2}{*}{$\begin{array}{l}\text { Kode } \\
\text { Beton }\end{array}$} & \multirow{2}{*}{$\begin{array}{l}\text { Nilai } \\
\text { fas }\end{array}$} & \multicolumn{2}{|c|}{$\begin{array}{l}\text { Perbandingan } \\
\text { Volume Bahan }\end{array}$} & \multicolumn{2}{|c|}{$\begin{array}{l}\text { Kuat Tekan Rerata } \\
\text { (MPa) }\end{array}$} \\
\hline & & & & Styrofoam & $\begin{array}{l}\text { Serbuk } \\
\text { Gergaji }\end{array}$ & Direndam & $\begin{array}{c}\text { Tidak } \\
\text { Direndam }\end{array}$ \\
\hline 1 & I & S250-ST100-SG0 & 0.400 & $100 \%$ & $0 \%$ & 0.24 & 0.29 \\
\hline 2 & II & S250-ST80-SG20 & 0.575 & $80 \%$ & $20 \%$ & 0.41 & 0.56 \\
\hline 3 & III & S250-ST60-SG40 & 0.775 & $60 \%$ & $40 \%$ & 0.15 & 0.13 \\
\hline 4 & IV & S250-ST40-SG60 & 1.075 & $40 \%$ & $60 \%$ & 0.70 & 0.74 \\
\hline 5 & $\mathbf{v}$ & S250-ST20-SG80 & 1.100 & $20 \%$ & $80 \%$ & 1.11 & 1.29 \\
\hline 6 & VI & S250-STO-SG100 & 1.450 & $0 \%$ & $100 \%$ & 0.92 & 1.12 \\
\hline 7 & I & S300-ST100-SG0 & 0.400 & $100 \%$ & $0 \%$ & 0.49 & 0.45 \\
\hline 8 & II & S300-ST80-SG20 & 0.525 & $80 \%$ & $20 \%$ & 0.70 & 0.85 \\
\hline 9 & III & $\begin{array}{l}\text { S300-ST60-SG40 } \\
\end{array}$ & 0.725 & $60 \%$ & $40 \%$ & 0.49 & 0.44 \\
\hline 10 & IV & S300-ST40-SG60 & 0.950 & $40 \%$ & $60 \%$ & 0.45 & 0.46 \\
\hline 11 & $\mathrm{v}$ & S300-ST20-SG80 & 1.000 & $20 \%$ & $80 \%$ & 1.11 & 1.38 \\
\hline 12 & VI & \begin{tabular}{|l} 
S300-STO-SG100 \\
\end{tabular} & 1.050 & $0 \%$ & $100 \%$ & $\frac{1.11}{1.48}$ & 1.83 \\
\hline 13 & I & S350-ST100-SGO & 0.400 & $100 \%$ & $0 \%$ & 0.43 & 0.58 \\
\hline 14 & II & S350-ST80-SG20 & 0.475 & $80 \%$ & $20 \%$ & 0.45 & $\frac{0.10}{1.13}$ \\
\hline 15 & III & S350-ST60-SG40 & 0.675 & $60 \%$ & $40 \%$ & 1.00 & 0.92 \\
\hline 16 & IV & S350-ST40-SG60 & 0.875 & $40 \%$ & $60 \%$ & 0.58 & 0.58 \\
\hline 17 & V & S350-ST20-SG80 & 0.850 & $20 \%$ & $80 \%$ & 1.29 & 1.63 \\
\hline 18 & VI & S350-STO-SG100 & 0.875 & $0 \%$ & $100 \%$ & 1.87 & 2.01 \\
\hline
\end{tabular}

Berdasarkan Tabel 7 diatas, terlihat kuat tekan rerata beton semakin besar seiring dengan berkurangnya persentase jumlah penggunaan styrofoam baik yang direndam maupun yang tidak direndam, hal ini menunjukkan bahwa semakin besar penggunaan serbuk gergaji maka nilai kuat tekannya menjadi lebih besar. Kuat tekan rerata beton tertinggi dicapai oleh beton dengan kandungan styrofoam 20\% dan 0\% atau pada kandungan serbuk gergaji sebesar $80 \%$ dan $100 \%$ Secara rerata beton dengan kondisi tidak direndam mempunyai kuat tekan yang lebih baik dari pada beton dengan kondisi direndam. Hal ini karena serbuk kayu gergajian mempunyai kelemahan akibat tingginya serapan air. Apabila kadar airnya besar kekuatan beton menurun.

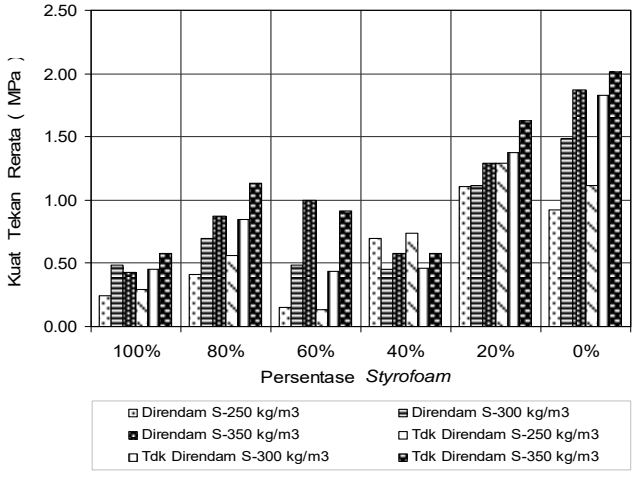

Gambar 6. Grafik hubungan berbagai variasi campuran dengan kuat tekan beton umur 28 hari

2. Penggolongan beton ringan berdasarkan kuat tekan beton.

Berdasarkan SNI 03-2847-2002[2] maka kuat tekan beton ringan ini termasuk kriteria struktur sangat ringan sebagai isolator, penggolongan Dobrowolski (1998)[4] termasuk untuk kriteria beton dengan berat jenis rendah, penggolongan Neville and Brooks (1987)[5] termasuk untuk kriteria beton ringan penahan panas dan menurut Satyarno (2004)[1] termasuk untuk kriteria beton non sturktur.

\section{E. Modulus Elastisitas Beton}

Modulus elastisitas beton diperoleh dengan menggunakan modulus sekan (secant modulus) dari kurva tegangan-regangan beton dengan Persamaan 6. Setiap variasi adukan diambil masing-masing 1 sampel benda uj i silinder.

Tabel 8. Modulus sekan beton ringan berdasarkan perbandingan campuran styrofoam, serbuk gergaji dan kandungan semen.

\begin{tabular}{|c|c|c|c|c|c|c|}
\hline No & $\begin{array}{l}\text { Kode } \\
\text { Beton }\end{array}$ & $\begin{array}{c}\text { Berat } \\
\text { Beton } \\
(\mathrm{kg} / \mathrm{m} 3)\end{array}$ & $\begin{array}{l}f^{\prime c} \\
\text { maks } \\
(\mathrm{MPa})\end{array}$ & $\begin{array}{l}0.5 \times f^{c} c \\
(\mathrm{Mpa})\end{array}$ & $\begin{array}{c}\varepsilon \\
\text { Sekan }\end{array}$ & $\begin{array}{c}\text { E Sekan } \\
\text { (MPa) }\end{array}$ \\
\hline 1 & 2 & 3 & 4 & 5 & 6 & 7 \\
\hline 1 & S250-ST100-SG0-D (A) & 306.287 & 0.22 & 0.11 & 0.00176 & 62.70 \\
\hline 2 & S250-ST80-SG20-D (A) & 447.300 & 0.34 & 0.17 & 0.00347 & 49.47 \\
\hline 3 & S250-ST60-SG40-D (A) & 601.996 & 0.14 & 0.07 & 0.00342 & 20.63 \\
\hline 4 & S250-ST40-SG60-D (A) & 834.249 & 0.75 & 0.37 & 0.00299 & 125.41 \\
\hline 5 & S250-ST20-SG80-D (A) & 916.537 & 0.96 & 0.48 & 0.00286 & 168.24 \\
\hline 6 & S250-ST0-SG100-D (A) & 1041.055 & 0.70 & 0.35 & 0.00289 & 120.54 \\
\hline 7 & S300-ST100-SG0-D (A) & 500.089 & 0.57 & 0.28 & 0.00258 & 109.72 \\
\hline 8 & S300-ST80-SG20-D (A) & 550.762 & 0.73 & 0.37 & 0.00330 & 111.25 \\
\hline 9 & S300-ST60-SG40-D (A) & 694.890 & 0.52 & 0.26 & 0.00477 & 55.00 \\
\hline 10 & S300-ST40-SG60-D (A) & 792.234 & 0.31 & 0.16 & 0.00117 & 133.60 \\
\hline 11 & S300-ST20-SG80-D (A) & 908.326 & 1.15 & 0.58 & 0.00303 & 189.91 \\
\hline 12 & S300-ST0-SG100-D (A) & 1088.021 & 1.54 & 0.77 & 0.00354 & 217.63 \\
\hline 13 & S350-ST100-SG0-D (A) & 414.939 & 0.38 & 0.19 & 0.00662 & 28.60 \\
\hline 14 & S350-ST80-SG20-D (A) & 628.075 & 0.82 & 0. & 0.00347 & 118.13 \\
\hline 15 & S350-ST60-SG40-D (A) & 698.583 & 0.92 & 0.46 & 0.00201 & 229.85 \\
\hline 16 & S350-ST40-SG60-D (A) & 847.911 & 0.71 & 0.35 & 0.00363 & 97.19 \\
\hline 17 & S350-ST20-SG80-D (A) & 971.701 & 1.42 & 0.7 & 0.00205 & 345.93 \\
\hline 18 & S350-ST0-SG100-D (A) & 1078.573 & 1.81 & 0.90 & 0.00327 & 276.17 \\
\hline 19 & S250-ST100-SG0-TD (A) & 384.576 & 0.38 & 0.19 & 0.00329 & 57.12 \\
\hline 20 & S250-ST80-SG20-TD (A) & 387.577 & 0.4 & 0. & 0.00215 & 112.02 \\
\hline 21 & S250-ST60-SG40-TD (A) & 458.844 & 0.12 & 0.06 & 0.00364 & 16.61 \\
\hline 22 & S250-ST40-SG60-TD (A) & 553.844 & 0.65 & 0.32 & 0.00229 & 141.36 \\
\hline 23 & S250-ST20-SG80-TD (C) & 732.864 & 1.47 & 0.7 & 0.00427 & 172.05 \\
\hline 24 & S250-ST0-SG100-TD (A) & 778.853 & 1.04 & 0.52 & 0.00480 & 107.98 \\
\hline 25 & S300-ST100-SG0-TD (A) & 422.752 & 0.50 & 0.25 & 0.00191 & 130.08 \\
\hline 26 & S300-ST80-SG20-TD (A) & 471.115 & 0.61 & 0.31 & 0.00147 & 208.08 \\
\hline 27 & S300-ST60-SG40-TD (A) & 558.994 & 0.34 & 0.17 & 0.00255 & 66.19 \\
\hline 28 & S300-ST40-SG60-TD (A) & 592.177 & 0.46 & 0.2 & 0.00207 & 110.24 \\
\hline 29 & S300-ST20-SG80-TD (A) & 709.533 & 1.38 & 0.69 & 0.00266 & 259.00 \\
\hline 30 & S300-ST0-SG100-TD (A) & 865.233 & 1.78 & 0.89 & 0.00352 & 252.93 \\
\hline 31 & S350-ST100-SG0-TD (A) & 436.216 & 0.73 & 0.36 & 0.00500 & 72.92 \\
\hline 32 & S350-ST80-SG20-TD (A) & 566.254 & 1.06 & 0.53 & 0.00214 & 247.43 \\
\hline 33 & S350-ST60-SG40-TD (A) & 635.313 & 0.86 & 0.43 & 0.00175 & 245.41 \\
\hline 34 & S350-ST40-SG60-TD (A) & 611.057 & 0.4 & 0. & 0.00077 & 303.25 \\
\hline 35 & S350-ST20-SG80-TD (A) & 744.617 & 1.58 & 0.79 & 0.00341 & 231.76 \\
\hline 36 & S350-ST0-SG100-TD (A) & 848.600 & 1.90 & 0.95 & 0.00323 & 294.41 \\
\hline
\end{tabular}

\section{KESIMPULAN}

Dari penelitian ini dapat diambil kesimpulan sebagai berikut :

1. Berat satuan styrofoam yang digunakan adalah $15.243 \mathrm{~kg} / \mathrm{m}^{3}$ dengan diameter beragam antara 2-7 mm. Berat satuan serbuk gergaji kayu jati adalah 283, 794 $\mathrm{kg} / \mathrm{m}^{3}$ kondisi jenuh kering muka (SSD) dengan modulus halus butir (mhb) yaitu 1,94 . 
2. Besarnya nilai faktor air semen (fas) sesuai dengan tingkat kelecakan yang mencukupi didapati bahwa makin besar persentase penggunaan serbuk gergaji maka nilai fas juga bertambah besar. Untuk fas minimum digunakan sebesar 0,40 sedangkan untuk fas maksimum yang digunakan sebesar 1, 45 .

3. Berat beton semakin bertambah seiring dengan semakin banyaknya persentase serbuk gergaji yang digunakan. Berdasarkan berat betonnya, menurut SNI 03-3449-1994 sampel beton termasuk golongan struktur ringan sebagai isolator, sedangkan menurut Dobrowolski (1998)[4] termasuk beton dengan berat jenis rendah, Neville and Brooks (1987)[5] termasuk beton ringan penahan panas dan menurut Satyarno (2004)[1] termasuk beton non struktur.

4. Kuat tekan rerata beton semakin besar seiring dengan semakin besar penggunaan serbuk gergaji baik yang direndam maupun tidak direndam. Kuat tekan rerata beton tertinggi dicapai oleh beton dengan kandungan styrofoam 20\% dan $0 \%$ berturut-turut sebesar 1,15 dan $1,54 \mathrm{MPa}$.

5. Nilai modulus elastisitas lebih besar ada pada variasi adukan yang persentase penggunaan serbuk gergaj $i$ lebih banyak dari styrofoam, bisa mencapai 0,00662.

\section{DAFTAR PUSTAKA}

[1] Satyarno, I., 2004, Seminar Nasional Inovasi Teknologi Bahan Bangunan untuk Meningkatkan PAD dan Beberapa Kemajuan untuk Menyelesaikan Permasalahan Bidang Teknik Sipil, Jurusan Teknik Sipil, Fakultas Teknik, Universitas Gadjah Mada, Yogyakarta.

[2] Departemen Pekerjaan Umum, 2002, Tata Cara Perencanaan Struktur Beton untuk Bangunan Gedung, SNI 03-2847-2002, Pusat Penelitian dan Pengembangan Pemukiman, Badan Penelitian dan Pengembangan, Dept. PU, Bandung.

[3] Departemen Pekerjaan Umum, 1994, Spesifikasi Bahan Bangunan Bagian A (Bahan Bangunan Bukan Logam), SNI
03-3449-1994, DPU Yayasan LPMB, Bandung.

[4] Dobrowolski, A.J., 1998, Concrete Construction Hand Book, The Mc. Graw Hill Companies, Inc., New York.

[5] Neville, A.M. and Brooks, J.J., 1987, Concrete Technology, J ohn Willey \& Sons, New York.

[6] Raju, K.N., 1983, Design of Concrete Mixes, CBS Publishers \& Distributors, 485, Jain Bhawan, Bhola Nath Nagar Shandra, Delhi-110032 (India).

[7] Tjokrodimuljo, K., 1996, Teknologi Beton, Nafiri, Yoyakarta.

[8] Sambodo, A.I., 2003, Penggunaan Styrofoam untuk Beton Ringan Dengan Kandungan Semen $350 \mathrm{~kg} / \mathrm{m}^{3}$, Tugas Akhir Jurusan Teknik Sipil, Fakultas Teknik Universitas Gadjah Mada, Yogyakarta

[9] Wijaya, S.N., 2005, Efek Perendaman Beton Styrofoam Ringan dengan Semen Portland Abu-Abu $250 \mathrm{~kg} / \mathrm{m}^{3}$, Tugas Akhir, Jurusan Teknik Sipil, Fakultas Teknik, Universitas Gadjah Mada, Yogyakarta.

[10] Sabbihiyah, 2005, Efek Perendaman Beton Styrofoam Ringan Dengan Semen Portland Tipe I $300 \mathrm{~kg} / \mathrm{m}^{3}$, Tugas Akhir, Jurusan Teknik Sipil, Fakultas Teknik, Universitas Gadjah Mada, Yogyakarta.

[11] Fatkhurohman., 2005, Efek Perendaman Beton Styrofoam Ringan Dengan Semen Portland Abu-Abu $350 \mathrm{~kg} / \mathrm{m}^{3}$, Tugas Akhir, Jurusan Teknik Sipil, Fakultas Teknik, Universitas Gadjah Mada, Yogyakarta.

[12] Tjokrodimuljo, K., 2004, Teknologi Beton, Buku Ajar, Jurusan Teknik Sipil, Fakultas Teknik, Universitas Gadjah Mada, Yogyakarta.

[13] Crawford, R.J., 1998, Plastic Engineering, Third Edition, John Willey \& Sons, New York.

[14] Ismeddiyanto, 1998, Penelitian Pemanfaatan Serbuk Gergaji Kayu Jati (Tectona Gandis L. F.) Untuk Bata Beton, Tugas Akhir, Jurusan Teknik Sipil, Fakultas Teknik, Universitas Gadjah Mada, Yogyakarta.

[15] Wang, C.K. dan Salmon C.G., 1986, Perencanaan Beton Bertulang, Edisi keempat, Penerbit Erlangga, J akarta. 